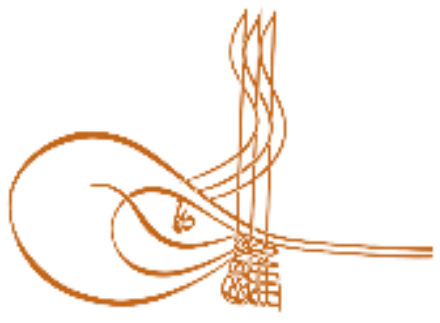

www.turkishstudies.net/social
Turkish Studies - Social Sciences

eISSN: $2667-5617$

Research Article / Araşttrma Makalesi

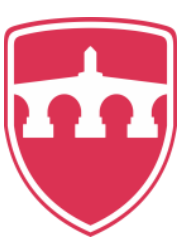

INTERNATIONAL

BALKAN

UNIVERSITY

Sponsored by IBU

\title{
Türkiye’nin Uluslararası Lojistik Performans Endeksindeki Konumunun Kümeleme Analizi ile Araștırılması
}

\author{
An Investigation of Turkey's Position in International Logistics Performance Index By Cluster \\ Analysis
}

Ali Yıldız - Kadir Aydoğan ${ }^{* *}$ - Göksel Kartum ${ }^{* * *}$

\begin{abstract}
At the point of providing competitive advantage in international trade, efficient implementation of logistics services has a strategic importance. In order to develop international trade, there are important tasks for companies as well as for governments to offer the goods and services to the market faster and more effectively than competitors. States should update their legislation on customs and logistics infrastructure in a way to create competition with other countries, and take measures and make regulations that will enable international shipments to be made faster. In this respect, countries have to determine the variables, strengths and weaknesses that affect their logistics performance. The aim of this study is to determine the Turkey's position in the international logistics performance index (LPI) between the years 2012-2018. Using the clustering analysis method, 90 countries with the highest foreign trade volume were included in the analysis. According to the results, Turkey has ranked 34th among the world countries and has shown performance above the average LPI. Turkey took part in the same cluster with Qatar, Malaysia, Portugal, Czech Republic, South Africa, China, Hungary and Poland in terms of logistics performance. According to the survey, Turkey has shown a better performance than the group of countries in the infrastructure variable. On the other hand, Turkey's performance was below the cluster group's performance in the customs, international shipments, logistic service quality and timeliness fields whereas the tracing/tracking variable was at the group average
\end{abstract}

\footnotetext{
* Dr. Öğr. Üyesi, Muğla Sitkı Koçman Üniversitesi, Seydikemer Uygulamalı Bilimler Y O, Muhasebe ve Finans Yönetimi Asst. Prof. Dr., Mugla Sitkı Koçman University, Seydikemer School of Applied Sciences, Department of Accounting and Financial Management 
level. It is thought that Turkey's LPI performance has improved and its ranking has raised as a result of the Turkey's large-scale investment in infrastructure in recent years.

Structured Abstract: The Logistics Performance Index (LPI) is a benchmarking tool that was developed by the World Bank to measure the logistic performance of countries on a six-variable basis. It helps them identifying the threats and opportunities they face in their logistics performance and improving the performances.

In order to improve the domestic and foreign trade capability of the countries and to increase the competitiveness of the countries, it is very important to make reforms in the logistics sector as well as the basic commercial activities. Within this scope there are important tasks for companies as well as for governments to offer the goods and services to the market faster and more effectively than competitors. States should update their legislation on customs and logistics infrastructure in a way to create competition with other countries, and take measures and make regulations that will enable international shipments to be made faster., In this respect, countries have to determine the variables, strengths and weaknesses that affect their logistics performance. Through the LPI, countries can compare themselves with competing countries in the international arena. In order to determine the logistics performance position and identifying the strengths and weaknesses in the global competition has strategic importance for Turkey as well.

LPI ranks countries on six dimensions of trade including customs performance, infrastructure quality, ease of arranging shipments, quality of logistics services, tracking and tracing and timeliness of shipments.

The aim of this study is to determine the Turkey's position in the international logistics performance index (LPI) between the years 2012-2018. The research was performed by hierarchical clustering analysis using SPSS 22 statistical program. The performances of the countries in International LPI were clustered in 20122018 period on the basis of logistic performance variables and Turkey's position was investigated. As the clustering method, the "nearest neighbor" is used from the single linkage clustering method, and the "euclidean distance" technique is used in determining the distance matrix.

The scope of the study consisted of 90 of 163 countries which has a foreign trade volume over 20 billion USD in 2017. The unweighted arithmetic averages of the selected countries' LPI scores related to 2012, 2014, 2016, 2018 are calculated and used in the analysis as a whole.

The number of the cluster is based on the distance of 12.5 units on the dendogram. Countries are collected in fourteen clusters. Turkey has taken part in the same cluster with Qatar, Malaysia, Portugal, Czech Republic, South Africa, China, Hungary and Poland. Turkey ranked 34th among the world countries and have shown high performance above the average LPI.

According to the results, Turkey has underperformed in the customs, international shipments, logistics service quality and punctuality variables compared to the cluster countries, which it take place. On the other hand, Turkey has showed better performance in the infrastructure variable and an average performance in the tracing variable compared to the cluster countries. According to OECD (2015) data, it is thought that Turkey's large-scale infrastructure investments improved the infrastructure performance in the LPI, so is thought to raise the rankings between countries. as follows:

Our suggestions for Turkey to come out of the top in the Logistic performance index can be offered

- By increasing investment in the maritime transport which is the most widely used transport mode in Turkey, an increase in productivity and efficiency can be achieved.

- The use of logistics information systems by enterprises can be expanded and it can be useful to integrate it among users in the logistics network.

- Turkey can improve the customs performance by reducing the physical control durations, waiting times and delays via focusing on electronic systems applications.

- In order to provide competitive prices, it can be ensured that load occupancy rates have to be increased, multi-mode transportation systems have to be integrated with eachother. The most appropriate transportation mode has to be selected for the target market and the number and efficiency of sea ports have to be increased.

Turkish Studies - Social, 15(3) 
- Accessing duration to the ports can be shortened by improving the connections of the ports with the inner regions. Logistics period can be shortened by increasing the connections between ports and production fields.

- In the long term, monitoring and quality control performance of logistics activities can be improved by investing more in information and communication technologies.

- In order to minimize the unforeseen situations and the delays in border crossings, cooperation has to be done with traded countries and the integration of logistic processes into the electronic platforms have to be ensured in internationally based.

In this study, the data set is based on the foreign trade volume of the countries. However, LPI performance also varies according to the income levels of the countries. Researchers can examine LPI performances based on countries' income levels or international economic associations. The performances of the countries in the same data set can be investigated based on different periods.

Keywords: Logistics Performance Index, Logistics Performance of Turkey, International Trade, LPI, Cluster Analysis.

Öz: Uluslararası ticarette rekabetçi üstünlüğün sağlanması noktasında lojistik hizmetlerinin etkin gerçekleştirilmesi stratejik öneme sahiptir. Uluslararası ticaretin geliştirilmesi için işletmelerin mal ve hizmetlerini rakiplere nazaran daha hızlı ve etkin şekilde pazara sunmasının yanında devletlere de düşen önemli görevler bulunmaktadır. Devletler, gümrük ve lojistik altyapısı konusunda mevzuatını diğer ülkelerle rekabet yaratacak şekilde güncellemeli, uluslararası sevkiyatların daha hızlı yapılabilmesinin önünü açan önlemler almak ve düzenlemeler yapmak durumundadır. $\mathrm{Bu}$ hususta ülkeler lojistik performanslarını etkileyen değişkenleri, güçlü ve zayıf yönlerini belirlemek durumundadır. Bu çalışmanın amacı 2012-2018 yılları arasında Türkiye'nin uluslararası lojistik performans endeksindeki (LPI) konumunu belirlemektir. Kümeleme analizi yöntemi kullanılarak, dış ticaret hacmi en yüksek 90 ülke analize dahil edilmiştir. Analiz sonuçlarına göre, Türkiye dünya ülkeleri arasında 34. sırada yer bularak LPI ortalamasının üzerinde performans göstermiştir. Türkiye lojistik performansında Katar, Malezya, Portekiz, Çekya, Güney Afrika Cumhuriyeti, Çin, Macaristan ve Polonya ile aynı kümede yer almıştır. Araştırma sonuçlarına göre, Türkiye, içinde bulunduğu kümede altyapı değişkeninde grup ülkelerine göre daha iyi performans göstermiştir. Buna mukabil gümrük, uluslararası sevkiyat, lojistik hizmet kalitesi ve dakiklik değişkenlerinde küme performansının altında kalırken, izleme değişkeninde ise grup ortalaması seviyesinde performans göstermiştir. Türkiye'nin son yıllardaki büyük çaptaki altyapı yatırımlarına verdiği önem neticesinde Türkiye’nin LPI performansını artırdığı ve böylece siralamasını yükselttiği düşünülmektedir.

Anahtar Kelimeler: Lojistik Performans Endeksi, Türkiye Lojistik Performansı, Uluslararası Ticaret, LPI, Kümeleme Analizi.

\section{Giriş}

Küreselleşme ve artan rekabet gücü, lojistiğin uluslararası ticarette kilit unsurlardan biri olmasını sağlamıştır. Verimli lojistik hizmetler, ürünlerin mobilitesini kolaylaştırmakta, güvenliğini ve hızını artırmaktadır (Martí vd. 2014:2982). Lojistik ve taşımacılık mikro ve makro anlamda bireyleri, firmaları, devletleri ve devletlerin üye olduğu uluslararası örgütleri ilgilendiren önemli bir unsurdur. Bu noktada, ticaretin gelişmesi adına ülkelerin almış oldukları önlemler, uyguladıkları politikalar ve düzenlemeler, ekonomik gelişmişlik düzeyleriyle doğru orantılıdır.

Lojistik ve taşımacılık sektörü, ticaret yapan firmaların ithalatını, ihracatını ve sundukları hizmetleri etkin şekilde yerine getirmesine imkân tanıyarak uluslararası ticaretin ayrılmaz bir parçası haline gelmiştir (Azmat, 2017:280). Sektör, tedarik zinciri yönetimi kavramının yaygınlaşmasıyla, tedarikten müşteriye kadar ürün akışını ileriye ve geriye doğru sağlayan önemli bir bağ olarak görülmektedir (Burmaoğlu, 2012:194). Performans ölçümünün ve değerlendirilmesinin öneminin gittikçe arttığı günümüzde küresel ve bölgesel bazda yapılan lojistik performans değerlendirmeleri 
ve bunlara ilişkin endeksler, dünya ticaretinin gelişmesi ve rekabeti açısından büyük öneme sahiptir (Ener, 2010:2).

Lojistik hizmetlerinin etkinliği, bir ülkenin rekabetçi yapısının belirleyicisidir. Etkin lojistik yönetimi; lojistik maliyetlerini de göz önünde bulundurarak verimliliği ve güvenirliliği artırmayı hedeflemektedir (Nordas vd, 2006:16-17). Uluslararası taşımacılık sisteminin gümrük gecikmeleri, uyumsuz standartlar veya gecikmelere ilişkin bilgi akışının yetersiz olması gibi lojistik ağ koordinasyonun zayıflığ 1 nedeniyle karşı karşıya kaldığ 1 noktalarda lojistik hizmetleri devreye girerek problemleri çözmeye yardımc1 olur (WTO1, 2004:120). Lojistikte kurumsal yönlerin gelişmişliği; yasal düzenlemelere, firma düzeyinde idari ve operasyonel usullere ve etkin tedarik zinciri yönetimine bağlıdır. Aynı zamanda etkin lojistik yönetimi kamusal politikalarla da oldukça yakından ilişkilidir (Azmat, 2017:280).

Bayraktutan ve Özbilgin (2015:98) lojistik performansın1; "lojistik hizmetlerin, sanayinin değişen ve çeşitlenen taleplerini karşılayabilme yeteneği, lojistik süreçlerdeki verimliliğin firmaların performansına ve rekabet gücüne katkısı, lojistik faaliyetler ile yaratılan katma değer kazanımı" olarak tanımlamıştır. Baki ve Şimşek (2004:2) ise lojistik performansını; "maliyet etkinliği, kârlılık, sosyal sorumluluk, zamanında teslim, verilen sözlerin tutulması, esneklik, müşteri memnuniyeti gibi hedeflerin başarılması" olarak tanımlamıştır.

Lojistik Performans Endeksi (LPI), Dünya Bankası tarafından yayınlanan, ülkelerin lojistik performanslarını altı değişken bazında ölçen, ülkelerin lojistik performanslarında karşılaştıkları tehdit ve fursatlar ile performanslarını iyileştirmek için neler yapabileceklerini belirlemelerine yardımcı olmak için oluşturulan bir kıyaslama aracıdır (World Bank1).

Ülkelerin iç ve dış ticaret yeteneğinin geliştirilmesi ve rekabet gücünün artırılabilmesi için temel ticari faaliyetlerin yanında lojistik sektöründe de reformların yapılması oldukça önemlidir (Sofyalıŏlu ve Kartal, 2013:527). Ülkelerin lojistik performanslarını ölçmek için Arvis vd. (2007) tarafından geliştirilen Lojistik Performans Ölçeği (LPI) ile ülkeler, uluslararası arenada kendilerini rakip ülkeler ile karşılaştırabilmektedir. Türkiye'nin lojistik performansının ve küresel rekabetteki yerinin belirlenebilmesi için zayıf ve güçlü yönlerinin tespit edilebilmesi stratejik öneme sahiptir. Türkiye'nin lojistik performansı, özel sektörün gelişmesine paralel olarak yükseliş göstermiştir. Bu anlamda Türkiye'nin lojistik performansının gelişmesi ve hizmet kalitesinin iyileştirilmesinde sanayi ve ticaret odaları katkı sağlamaktadır (OECD, 2015:5). Akçetin (2010:12) bir ülkenin lojistik üssü olabilmesi için coğrafi avantaja, fiziksel ve kurumsal alt yapıya sahip olmalarına bağlı olduğu sonucuna ulaşmış; Türkiye'nin coğrafi avantajının olduğunu ancak fiziksel ve kurumsal altyapının çağdaş lojistik düzeyine çıkarılması gerektiğini vurgulamıştır. Türkiye İstatistik Kurumu (TÜIK, 2018) verilerine göre 2002 y1lından itibaren Türkiye'nin dış ticaret hacmi \%11,9 artış göstermiştir. Bu çalışma uluslararası LPI'ya göre 2012-2018 yılları arasında Türkiye'nin konumunu ve hangi ülkeler ile benzerlik gösterdiğini araştırmayı amaçlamıştır. LPI alt bileşenleri bazında Türkiye’nin dünyadaki konumu araştırılmıştır.

\section{Lojistik Performans Endeksi Kavramı}

Lojistik Performans endeksi (LPI), ilk kez 2007'de, daha sonra sırasiyla 2010, 2012, 2014 , 2016 ve 2018 yıllarında yayınlanmıştır. Endeks iki yılda bir güncellenen ülkelerin lojistik alanındaki performanslarını ölçmek için Dünya Bankası tarafından oluşturulmuştur. LPI, ülkelerdeki çeşitli lojistik işletmelerindeki çalışan ve yöneticilerin, Finlandiya'da bir üniversitede hazırlanan anket sorularına verdiği cevaplara göre belirlenmektedir. Hâlihazırda lojistik performansını ölçebilen tek endeks LPI'dır (Arvis vd., 2016). Ranjit (2016:12) ise bu endeksin küresel etkinlik ölçümünde yetersiz kaldığını belirterek, yüksek, orta ve düşük gelirli ekonomiler arasında da etkinlik analizini yapabilen yeni araştırma yönteminin gerekliliğini vurgulamıştır. Bu endeks, analiz edilmek üzere ülkeler arasındaki gümrük işlemleri, lojistik maliyetler ve kara ve deniz taşımacılığı için gerekli 
altyapının kalitesi alanında önemli farklılıklara genel bir bakış açısı sağlamaktadır (Martí vd. 2014:2983).

LPI uluslararası ve ulusal olmak üzere iki bölümden oluşmaktadır. Dünya Bankası'nın 2018'de yayınladığı uluslararası LPI 160 ülkeyi kapsarken; ulusal LPI 100 ülkeyi kapsamaktadır (Arvis vd., 2018:10). Bu endeks, devlet ve şirketlere ulusal ve küresel rekabette ayakta kalabilmeleri için strateji geliştirmelerine imkan vermektedir (Martí vd., 2017).

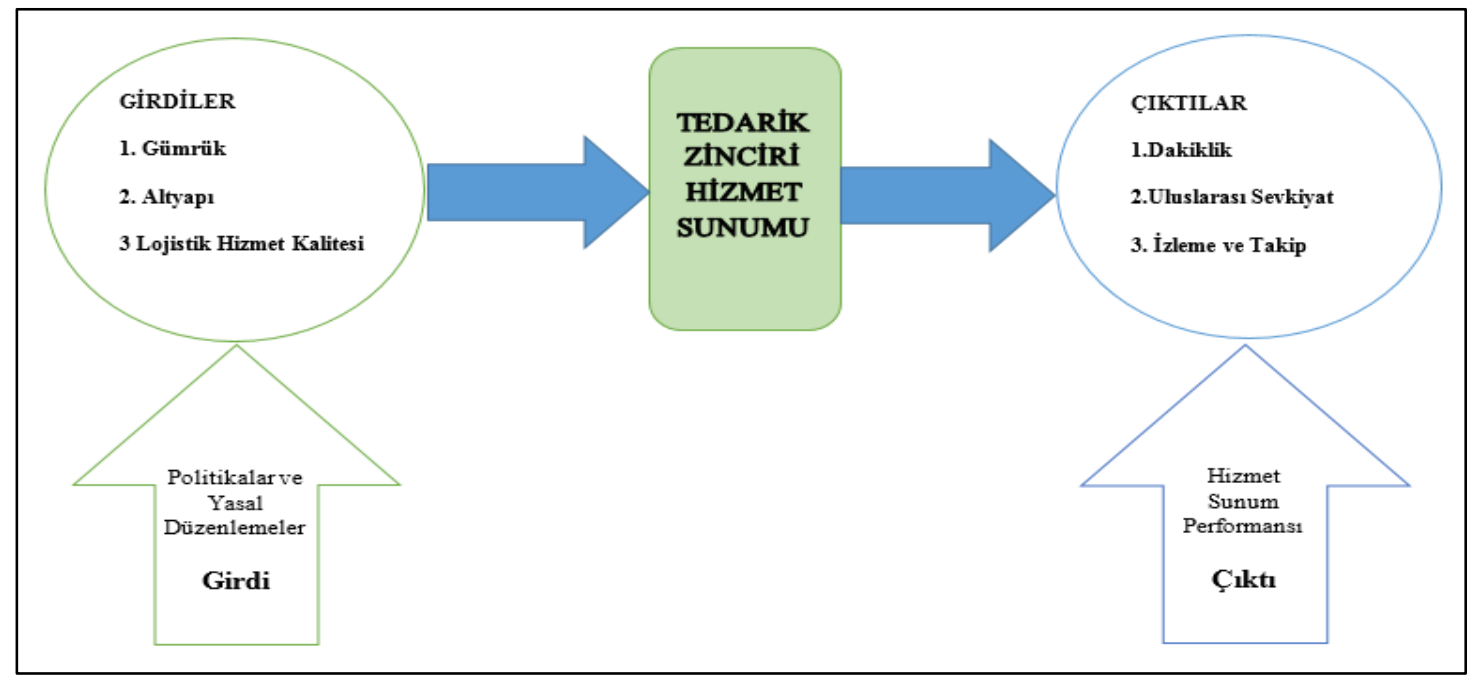

Şekil 1: LPI göstergelerine göre girdiler ve çıktılar (Kaynak: Arvis vd., 2014)

Şekil 1'de Arvis vd. (2014:7) gümrükler, altyap1 ve hizmet kalitesi değişkenlerini politika düzenlemeleri ile ilişkilendirerek girdi olarak belirlerken; dakiklik, uluslararası sevkiyatlar, takip ve izleme değişkenlerini ise hizmet dağıtım performansıyla ilişkilendirip, çıktı olarak nitelendirilmiştir. Sınır işlemleri konusunda ülkeler arasında sınırlı koordinasyon, lojistik hizmetlerinin etkinliği, limanlardaki gümrükleme işlemlerinin hızı, ulaştırma ile ilgili altyapının durumu, yüksek maliyetli ve parsiyel sevkiyatların sayısı, sevkiyat takibinde zamanlama, terminalde malların elleçlenme süresi gibi hususlar uluslararası ticarette lojistik performansının önemini ortaya koymaktadır (Azmat 2017).

Tablo 1'de yıllara göre Türkiye'nin genel LPI ve alt bileşenleri bazında dünya sıralamasına yer verilmiştir. Genel LPI sıralamasına bakıldığında Türkiye'nin 2016-2018 aralığında 2012-2016 dönemine göre keskin bir gerileme kaydettiği görülmektedir. Benzer gerilemenin gümrük, uluslararası sevkiyatlar ve lojistik hizmet kalitesi bileşenlerinde de yaşandığı görülmektedir. Dakiklik değişkeninde 2012 yılından itibaren kayda değer bir gerileme yaşanırken; izleme ve takip değişkeninde ise 2014 yılından sonra önemli gerileme yaşandığı görülmektedir. Altyap1 değişkeninde de Türkiye'nin gerileme kaydettiği izlenmekte iken, diğer değişkenlere nazaran daha iyi performans gösterdiği ifade edilebilir.

Tablo 1: Türkiye'nin Dünya LPI Sıralamasındaki Yeri

\begin{tabular}{|c|c|c|c|c|c|c|c|}
\hline Yıllar & $\begin{array}{c}\text { Genel } \\
\text { LPI }\end{array}$ & Gümrük & Altyapı & $\begin{array}{c}\text { Uluslararası } \\
\text { Sevkiyatlar }\end{array}$ & $\begin{array}{c}\text { Lojistik } \\
\text { Kalitesi }\end{array}$ & $\begin{array}{c}\text { İzleme ve } \\
\text { Takip }\end{array}$ & Dakiklik \\
\hline $\mathbf{2 0 1 2}$ & 27 & 32 & 25 & 30 & 26 & 29 & 27 \\
\hline $\mathbf{2 0 1 4}$ & 30 & 34 & 27 & 48 & 22 & 19 & 41 \\
\hline $\mathbf{2 0 1 6}$ & 34 & 36 & 31 & 35 & 36 & 43 & 40 \\
\hline $\mathbf{2 0 1 8}$ & 47 & 58 & 33 & 53 & 51 & 42 & 44 \\
\hline
\end{tabular}

(Kaynak: WorldBank1) 
LPI, ülkeleri altı değişken bazında incelemektedir. Bunlar; gümrük ve sınır yönetim verimliliği, ticaret ve ulaştırma altyapı kalitesi, rekabetçi sevkiyat fiyatlarının ayarlanabilmesi kolaylığı, lojistik hizmetlerinin kalitesi ve yeterliliği, sevkiyatların izlenme ve takip edilebilirliği ile sevkiyatların alıcılara beklenen sürelerde ulaştırılma sıklığıdır (Arvis vd., 2010, 2012, 2014, 2016, 2018).

\section{A. Gümrük ve Sınır Yönetiminin Verimliliği (Gümrük)}

Gümrükleme ve sınır yönetiminin verimliliği daha çok kamu politikaları ve yatırımlar ile ilgili bölümdür (Demir 2013:8-9). Bu bakımdan verimlilik; gümrük idarelerinin şeffaflığı, ithalat ve ihracat süresi, bürokratik işlemlerin tamamlanma süresi, işlemlerin çevrimiçi yürütülebilmesi, dokümantasyonun basitleştirilmesi, gümrük beyanının yetkili bir gümrük müşaviri tarafından yapılabilmesi, sonuç işlemlerinin istenilen gümrükten yapılabilmesi, fiziki kontrol süreçlerinin hızı ve maliyeti, gümrükte yaşanan beklemeler ve gecikmeler ile teslim süreleri hususlarından oluşmaktadır (Arvis vd., 2014:39).

Uluslararası ticaret hacminin son yirmi yılda hızla artışı, yavaş, pahalı ve zaman alan operasyonel bürokrasinin modernize edilmesini gerektirmektedir (Azmat 2017:280). Puertas vd. (2014:477) ülkelerin, gümrükleri modernize ederek uluslararası rekabet güçlerini arttıracağını belirtmiştir.

Türkiye'nin gümrük işlemleri yetkinliği, bilgi ve iletişim teknolojilerindeki ilerlemeye bağl1 olarak iyileşme kaydetmiştir. Gümrük işlemlerinin sadeleştirilmesi ve otomasyonu, geliştirilmiş bilgi teknolojileri sayesinde artan verimlilik artışı, yönetim ve insan kaynağının niteliğindeki artış gümrük yönetimindeki gelişmeye katkıda bulunmuştur (OECD, 2015:5).

\section{B. Ticaret ve Ulaştırma Altyapısının Kalitesi (Altyapı)}

Lojistik faaliyetler, sadece dış ticaret hacmi, yatırım düzeyi, iktisadi büyüme gibi unsurlarla değil, ulaştırma altyapısına bağlı olarak da gelişme göstermektedir (Bayraktutan ve Özbilgin, 2015:109). Ticaret ve ulaştırma altyapısının kalitesi; limanlar, hava limanları, karayolları, demiryolları, depolama ve taşıma tesisleri ile telekomünikasyon ve bilgi teknolojilerinin performansına bağlı olarak ölçülmektedir (Arvis vd., 2014:38).

Günümüzde ülkelerin, bölgelerin ve şehirlerin lojistik altyapı gelişmişliğine göre sıralandığı bir ortamda işletmelerin, uluslararası nakliye, depolama, stok kontrolü, paketleme, etiketleme, sevkiyat, gümrükleme ve dağıtım gibi konularda yeterli hizmet alabilmesinde ulaştırma altyapısının ve ulaştırma sistemlerinin kalitesi vazgeçilmez bir unsurdur (Bayraktutan ve Özbilgin, 2015:96).

Saatçioğlu ve Karaca (2013:1), ulaştırma altyapısının, karayolu, demiryolu, denizyolu, havayolu, iç suyolları ve boru hatlarından oluştuğu vurgulamıştır. Ayrıca, ulaştırma altyapısı gelişiminin bölgesel kalkınma için bir ön şart olduğunu, taşıma maliyetlerini indirerek ticareti ve uzmanlaşmayı teşvik edeceğini vurgulamıştır. Meçik (2012:30-31) ise ulaştırma altyapısının gelişmişliği ile ülkelerin ekonomik entegrasyonu arasında pozitif bir ilişki olduğunu belirtmiştir. Aşılması güç coğrafi engeller, ülkelerin dış ticaretini, ekonomik büyümesini (Azmat, 2017) ve dolayısıyla lojistik performansını olumsuz yönde etkileyebilmektedir. 


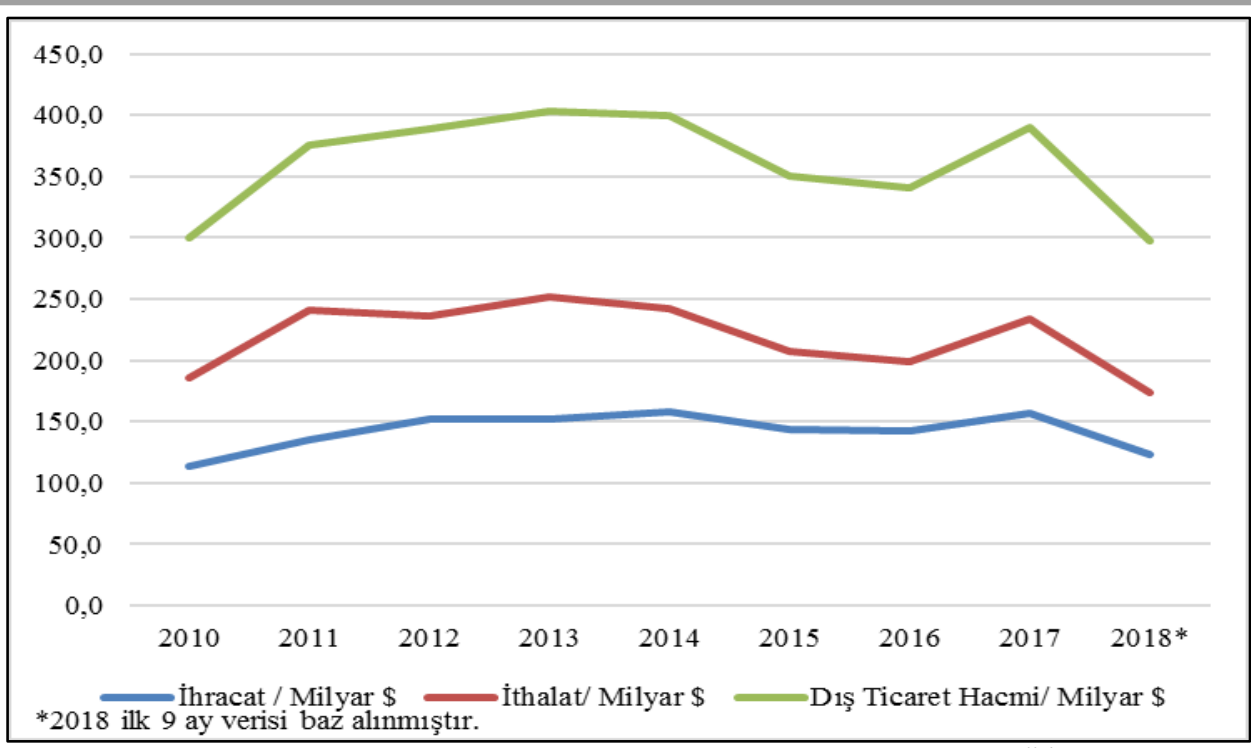

Şekil 2: Türkiye’nin 2010-2017 Arası Dış Ticaret Grafiği (Kaynak: TÜíK, 2018)

Şekil 2'de Türkiye'nin 2010-2017 arasındaki dış ticaret performansı görülmektedir. Sekiz y1llık sürede ihracat rakamlarının 100 ila 157 milyar dolar arasında seyrettiği görülmektedir. İthalat rakamlarının ise dalgalı bir seyir izleyerek 185 ila 251 milyar dolar arasında gerçekleştiği izlenmiştir. Türkiye dıș ticaret hacminin 2014 yılına kadar kademeli olarak artış gösterdiği, 2014-2016 aralığında ciddi azalış gösterdiği ve 2016-2017 döneminde ise tekrar ivme kazanarak artış kaydettiği görülmektedir. 2018 yılında uluslararası para birimlerinde yaşanan hareketliliğin Türk Lirası üzerindeki olumsuz etkileri dıș ticaret hacmini olumsuz yönde etkilemiștir. İthalat ve ihracat rakamlarının genel olarak birbirine paralel biçimde artış ve azalış gösterdiği not edilmelidir.

Büyük çapta yol yatırımları, LPI'da Türkiye'nin altyapı performansının iyileştirilmesine yardımcı olmuştur. Uluslararası yük taşımacıları, LPI araştırmasında lojistik performansını doğrudan değerlendiren birimlerdir. Dolayısıyla, yol altyapısındaki herhangi bir iyileşmenin doğrudan LPI skoruna olumlu yansıması muhtemeldir (OECD, 2015:5). 2016 yılı Ulaştırma ve Altyapı Bakanlığı raporuna göre 2003-2016 yılları arasındaki toplam 337,3 milyar TL yatırımın \%1,2'si denizyolu, $\% 7,9$ 'u havayolu, $\% 9,5$ 'i haberleşme, \%18'i demiryolu, \%63,4'ü karayolu sektörüne yönelik yapılmıştır (UAB, 2016). Şekil 3'te 2016 yılı Türkiye dış ticaretinin taşıma modlarına göre dağılımı verilmiştir. Buna göre toplam 341,2 milyar dolarlık dış ticaret hacminin \%58,26'sının deniz yoluyla taşındığ görülmektedir.

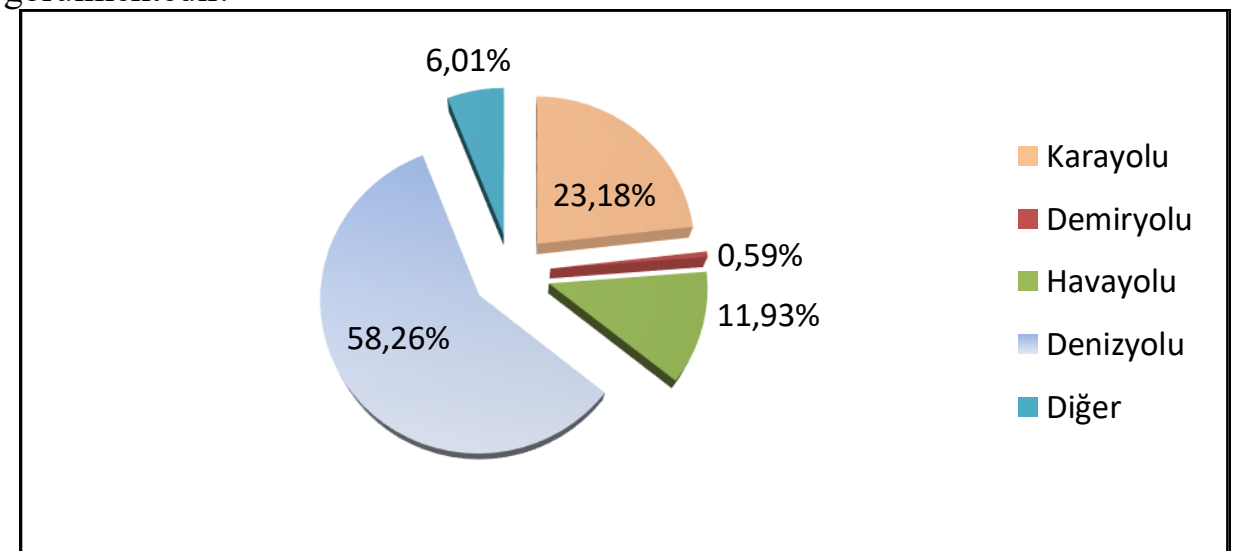

Şekil 3: 2016 Yılı Türkiye Dış Ticaretinin Taşıma Modlarına Göre Dağılımı

(Kaynak: UAB, 2016; http://www.udhb.gov.tr/images/istatistik/2003-2016.pdf) 


\section{Sevkiyatlar) \\ C. Rekabetçi Sevkiyat Fiyatlarının Ayarlanabilmesi Kolaylığı (Uluslararası}

Taşımacılık sistemlerinin verimliliği sektör karlılığı ile yakından ilişkilidir. Taşımacılık maliyetlerinin minimuma indirilmesi rekabetçi üstünlüğün temel göstergelerinden biridir (Ojala ve Çelebi, 2015:7). Maliyetleri düşürmek işletmelere esnek fiyat düzenleme imkânı vererek piyasadaki rekabet gücünü arttırmaktadır.

Lojistik işletmeleri dış kaynak kullanımı ile temel faaliyet alanına odaklanarak rekabet üstünlüğünü sağlamaya yönelik stratejiler geliştirmektedir (Onay ve Kara, 2009:594). Günümüzde lojistik yöneticileri, yoğun rekabetçi ortamda ayakta kalabilmek için müşterilere verimlilik ve etkinlikten daha fazlasını sunan en yüksek katma değeri sağlamak zorundadır (Fugate vd., 2010:43). Sürdürebilirlik açısından işletmeler bu değeri, kıt olan kaynaklarla ve rekabetçi fiyatlarla sunmak zorundadir.

İç taşımacılıkta Türkiye'nin ağırlıklı olarak kullandığı karayolu ulaşım sistemi, yüksek taşımacılık maliyetlerini de beraberinde getirmektedir. Bu maliyetlerin \%50'sinden fazlası yakıt maliyetlerinden oluşmaktadır (OECD 2015:5).

\section{Lojistik Hizmetlerinin Kalitesi ve Yeterliliği (Lojistik Hizmet Kalitesi)}

Lojistik hizmet kalitesi, lojistik performansında müşterilerin beklentilerini karşılamanın önemine işaret etmektedir (Demir, 2013:8-9). Arvis vd. (2014) ise lojistik hizmetlerinin kalitesi ve yeterliliğini; karayolu taşımacılığı, havayolu taşımacılığı, denizyolu taşımacılığı, depolama ve dağıtım kanallarının etkin kullanılması ve taşıma komisyoncuları, gümrük kuruluşları, kalite kontrol kuruluşları, gümrük müşavirlikleri, ticaret ve sanayi odaları ile alıcılar ya da satıcıların performansı ile ilişkilendirmiştir. Bayraktutan ve Özbilgin (2015) lojistik hizmet kalitesi ile ürünlerin alıcıya zamanında ulaştırılmasını sağlayan başarılı lojistik faaliyetlerinin birleşimi sonucunda lojistik performansının oluşacağını ifade etmiştir.

Türkiye'de limanların iç bölgelerle bağlantılarının az gelişmiş olması ve limanların, uluslararası limanlar ve üretim sahaları ile bağlantılarının zayıf olması Türkiye'nin LPI performansını ve limanların yük taşıma kapasitelerini kısıtlamaktadır (OECD, 2015).

\section{E. Sevkiyatların İzlenme ve Takip Edilebilirliği (İzleme ve Takip)}

Sevkiyatların her bir adımının takip edilmesi ve son müşteriye teslim edilmesine kadar yük hareketlerini belirlenmesi önem arz etmektedir. İzlenebilirlik, bir bütün olarak lojistik sektörünün bir ürünü olmakla beraber, tedarik zincirindeki tüm taraflar bu bileşene katkıda bulunmaktadır. Gelişmiş izlenebilirlik, dağıtım kanalı süreçlerin daha güvenilir ve risk yönetim sisteminin daha etkin olmasına yardımc1 olur (OECD, 2015). Takip edilebilirlik ise lojistik alanında bilgi teknolojilerinin etkin kullanımı ile yakından ilgilidir (Demir 2013:8-9). Dolayısıyla işletmeler, bilgi ve iletişim teknolojileri kullanarak daha fazla işbirliği, kalite kontrolü ve etkin dağıtım planları sağlayan gelişmiş lojistik modülleri oluşturabilirler.

Gülenç ve Karagöz (2008) Türkiye'de elektronik lojistiğin, işletmelerin çoğu tarafından ağır bir maliyet unsuru olarak görüldügünü, bilişim teknolojilerine daha fazla önem verilmesi ve yatırım yapılması gerektiğinin farkında olmalarına rağmen kısa ve orta vadeli planlarında düşünmediklerini belirtmiştir.

\section{F. Sevkiyatların Alıcılara Beklenen Sürelerde Ulaştırılma Sıklığı (Dakiklik)}

Gönderilerin, varış yerine zamanında veya zamanından önce ulaşması, teslimat süreleri bakımından güvenilirliği artırır. Sevkiyat süreleri; ürün cinsi, sevkiyat planı ve yönetimi, lojistik hizmetleri, mesafe, politik riskler ve hava koşulları gibi çeşitli faktörlere bağlıdır (OECD, 2015:44). 
İşletmelerin hızlı yanıt verebilecek bilgi teknolojilerine sahip olmaları ve tam zamanında tedarik programları için etkili müşteri cevap girişimlerini önemsemeleri sürdürebilir lojistik açısından stratejik öneme sahiptir (Burmaoğlu, 2012:196). Lojistik ağında entegrasyon en önemli konulardan birisidir. Gerek üretim-malzeme yönetimi gerekse fiziksel dağıtımdaki entegre sistem, sevkiyatların zamanında ulaştırılmasını sağlamaktadır.

Dış faktörler ve politik riskler, taşımacılık maliyetlerini arttırıp, dakiklik performansını azaltmaktadır. Türkiye'ye komşu ülkelerdeki siyasi istikrarsızlık ve savaş sevkiyatların yeniden yönlendirilmesine ve teslim sürelerinde gecikmelere yol açmıştır. Özellikle sınır geçişlerinde belirsizlik, öngörülemeyen durumlar ve gecikmeler işlem maliyetlerini artırmaktadır (OECD, 2015:5).

\section{LPI Literatür Çalışmaları}

LPI konusunda yapılan yerli araştırma sayısının yabancı araştırmalara nazaran az olduğu görülmekle birlikte, son yıllarda LPI konusuna gösterilen ilginin arttığı görülmüştür. Literatürde LPI konusunda yapılan çalışmalardan bazıları aşağıda Tablo 2'de özetlenmiştir.

Tablo 2: LPI ile İlgili Literatür Çalışmaları

\begin{tabular}{|c|c|}
\hline Çalışma Bilgisi & Çalışma Konusu ve Özeti \\
\hline Çelebi ve Civelek (2019) & $\begin{array}{l}\text { Lojistik performans ve insani gelişmişlik arasında olup olmadığına bakmakta ve } \\
\text { her iki kavramla da ilişkili olan küresel bağlantılllığın ara değişken rolünü } \\
\text { incelemiştir. }\end{array}$ \\
\hline $\begin{array}{l}\text { Ofluoğlu, Kalaycı, Artan } \\
\text { ve Bal (2018) }\end{array}$ & $\begin{array}{l}\text { Lojistik performansındaki gelişmelerin Avrupa Birliği ve MENA ülkelerinin } \\
\text { uluslararası ticareti üzerindeki etkileri araştırılmıştır. Ülkelerin lojistik performans } \\
\text { endeksi ve alt bileşenler, uluslararası ticaret performansının açıklanmasında } \\
\text { önemli rol üstlenmektedir. }\end{array}$ \\
\hline $\begin{array}{l}\text { Yapraklı ve Ünalan } \\
\text { (2017); Kunadhamraks ve } \\
\text { Hanaoka (2008); Martí, } \\
\text { Puertas ve García (2014); } \\
\text { Mundial (2011); Navickas } \\
\text { Sujeta ve Vojtovich } \\
\text { (2011) ve }\end{array}$ & Lojistik performans ölçütlerinin etkinliğini ve verimliliğini araştırmıştır. \\
\hline Başar ve Bozma (2017) & $\begin{array}{l}\text { Lojistik Performans Endeksinin (LPI) makroekonomik ve politik belirleyicileri } \\
\text { ortaya koyulmaya çalışılmıştır. GSYH ve dış açılık, LPI'yı açıklayan önemli } \\
\text { makroekonomik değişkenler olduğunu tespit edilmiştir. Bunun yanı sra } \\
\text { demokratik hesap verebilirlik ve diş karışılklı̆̆ı ülkelerin lojistik performanslarını } \\
\text { belirlemede etkili olduğu ortaya koyulmuştur. }\end{array}$ \\
\hline Mutlu ve Ölmez (2017) & İlişki kalitesi değișkenleri ile lojistik performans kavramlarını incelemiștir. \\
\hline $\begin{array}{l}\text { Khan, Qianli, SongBo, } \\
\text { Zaman ve Zhang (2017); } \\
\text { Hung (2011) }\end{array}$ & Çevresel ve yeşil lojistik performans endeksini araştırmıştır. \\
\hline Akiş (2016) & $\begin{array}{l}\text { Türkiye'nin lojistik sektörü ve Lojistik Performans Endeksi'ndeki yeri Global } \\
\text { Rekabet Gücü Endeksi incelenmiştir. }\end{array}$ \\
\hline Çakmak (2016) & $\begin{array}{l}\text { Türkiye'nin ticaretini geliştirmesi için lojistik hizmetlerini, hava ve kara yolu } \\
\text { altyapısını ve gümrük hizmetlerini geliştirmeli; gümrük idarelerinin etkinliğini, } \\
\text { bilişim ve iletişim teknolojilerinin kullanımını ve güvenlik koşullarını } \\
\text { iyileştirmelidir. }\end{array}$ \\
\hline $\begin{array}{l}\text { Bayraktutan ve Özbilgin } \\
\text { (2015) }\end{array}$ & $\begin{array}{l}\text { Ülkelerin/bölgelerin lojistik performansı üzerinde etkili olan ve lojistik sektörünün } \\
\text { büyüklüğünü yansıtan parametreler sınıflandırılmıştır. Temel performans } \\
\text { göstergeleri, faktör koşulları, iktisadi koşullar ve dış çevre koşulları şeklinde üç } \\
\text { gruba ayrılmıştır. }\end{array}$ \\
\hline
\end{tabular}




\begin{tabular}{|c|c|}
\hline Yu ve Hsiao (2016) & $\begin{array}{l}\text { Bireysel ülkelerin lojistik performans endeksini Dünya Bankasından farklı bir } \\
\text { yöntem kullanarak Dea-Ar meta modeliyle araştırmıştır. }\end{array}$ \\
\hline $\begin{array}{l}\text { Akçetin, Çelik ve Takçı } \\
\text { (2015) }\end{array}$ & $\begin{array}{l}\text { Türkiye'nin lojistik performans indeksindeki pozisyonunu veri madenciliği } \\
\text { yoluyla araştırmıştır. }\end{array}$ \\
\hline $\begin{array}{l}\text { Civelek, Uca ve Çemberci } \\
\text { (2015); D'Aleo (2015) }\end{array}$ & $\begin{array}{l}\text { Lojistik performans indeksine aracılık etkisi olan değişkenleri araştırmıştır. Gayri } \\
\text { safi milli hasıla ve küresel rekabetçilik endeksi arasındaki ilişkinin aracıllk rolünde } \\
\text { anlamlı olduğunu analiz etmiştir. }\end{array}$ \\
\hline Gergin ve Baki (2015) & Türkiye'deki yedi coğrafi bölgenin lojistik performansını incelemiștir. \\
\hline Erkan (2014) & $\begin{array}{l}\text { Lojistik performans indeksi ile küresel rekabetçilik endeksi arasındaki ilişkiyi } \\
\text { incelemiştir. Demiryolu ve liman altyapı kalitesinin artırılmasını bulgulamıştır. }\end{array}$ \\
\hline Arvis vd. (2014) & $\begin{array}{l}\text { Küresel boyutta lojistik hizmetlerinin durumunu incelemiştir. LPI indeksi ve } \\
\text { bileşenleri araştırılmıştır. }\end{array}$ \\
\hline $\begin{array}{l}\text { Puertas,Martí ve } \begin{array}{l}\text { García } \\
\text { (2014); }\end{array} \text { Vilko, } \\
\text { Karandassov ve } \text { Myller } \\
(2011)\end{array}$ & Lojistik performans endeksi ile ülkelerin rekabetçiliğini araştırmıştır. \\
\hline $\begin{array}{l}\text { Sofyalıoglu ve Kartal } \\
\text { (2013) }\end{array}$ & $\begin{array}{l}\text { Türkiye ile Avrasya Ekonomik Topluluğu arasında lojistik performans endeksini } \\
\text { araştırmıştır. Altyapı hizmetleri ve bilgi teknolojilerine yatırım yapılmas } \\
\text { gerektiğini önermiştir. }\end{array}$ \\
\hline $\begin{array}{l}\text { Bayraktutan, Tüylüoğlu } \\
\text { ve Özbilgin (2012) }\end{array}$ & $\begin{array}{l}\text { Kocaeli’ndeki lojistik sektörünün durumu ve kentin lojistik potansiyeli ele alınmış } \\
\text { ve bölgede sektörün güçlü bir yoğunluğa sahip olduğu anlaşılmıştır. Kocaeli’nin, } \\
\text { Türkiye'de iller düzeyinde sektörün gelişmişliği bakımından yüksek endeks değeri } \\
\text { ile öne çıktığı görülmüştür. }\end{array}$ \\
\hline Güner ve Coşkun (2012) & $\begin{array}{l}\text { Ülkelerin lojistik performansı üzerinde ekonomik ve sosyal faktörlerin etkisini } \\
\text { araştırmış ve sosyal faktörlerin daha etkili olduğunu analiz etmiştir. }\end{array}$ \\
\hline Havenga (2011) & Güney Afrika’nın lojistik sisteminin performansını araştırmıştır. \\
\hline Ener (2010) & $\begin{array}{l}\text { Mersin'de faaliyet gösteren lojistik firmalarının lojistik performansını incelemiş } \\
\text { ve firmaların performanslarının Türkiye ortalamasının üzerinde olduğunu analiz } \\
\text { etmiştir. }\end{array}$ \\
\hline
\end{tabular}

(Kaynak: Yazar tarafindan oluşturulmuştur.)

\section{Metodoloji}

Araştırma SPSS 22 istatistik programı kullanılarak hiyerarşik kümeleme analizi ile yapılmıştır. Uluslararası LPI'da yer alan ülkelerin 2012-2018 dönemine ilişkin performansları lojistik performans değişkenleri bazında gruplanmış ve Türkiye'nin konumu araştırılmıştır.

\section{A. Araştırmanın Kapsamı ve Sınırlılıkları}

Araştırma kapsamına Dünya Bankasınca LPI kapsamına alınan 163 ülkeden, 2017 yılı itibari ile dış ticaret hacmi 20 milyar dolar ve üzerinde olan 90 ülke dahil edilmiştir (WTO2). Kümeleme analizi 163 ülke ile yapıldığında hariçte bırakılan ve ticaret hacmi düşük düzeyde olan ülkelerin, ülkemiz ile aynı grupta yer almadığı gözlenmiştir. Bu bakımdan, verilerin daha anlaşılabilir ve sade olabilmesi adına düşük hacimli ülkeler kapsam dışı bırakılmıştır. Seçilen ülkelerin 2012, 2014, 2016, 2018 yılı ağırlıklandırılmamış LPI skorlarının aritmetik ortalamaları hesaplanarak, bir bütün halinde analiz edilmiştir.

\section{B. Araştırmanın Yöntemi ve Değişkenleri}

Araştırmada çok değiş̧kenli istatistik tekniklerden birisi olan kümeleme analizi yönteminden yararlanılmıştır. Kümeleme analizi, bireylerin ya da nesnelerin sınıflandırılmasını ayrıntılı bir şekilde açıklamak amacıyla geliştirilmiştir. Bu amaca yönelik olarak, ele alınan örnekte yer alan varlıklar aralarındaki benzerliklere göre gruplara ayrılır, daha sonra bu gruplara dâhil edilen varlıkların profili ortaya konur. Bir başka ifade ile kümelemenin amacı, öncelikle ele alınan örnekte gerçekte var olduğu bilinen varlıklar (birey ya da nesne) arasındaki benzerliklere dayanan az sayıdaki karşılıklı özel grupları oluşturmak, daha sonra bu gruplara giren varlıkların profilini ortaya koymaktır. Diğer 
bir hedef ise benzer elemanların gruplanmasıyla veri setini küçültmektir (Sarıman, 2011:193). Veriler, SPSS 22 programında Hiyerarşik Kümeleme Analizi ile araştırılmıştır. Kümeleme metodu olarak Tek Bağlantı Kümeleme Yöntemi'nden en yakın komşu (nearest neighbour), mesafe matrisinin belirlenmesinde öklit uzaklı̆̆ (euclidien distance) tekniği kullanılmıştır (Yılmaz ve Patır, 2011:103). Araştırmada kullanılan faktör değişkenler 6 kriter halinde altta yer almaktadır. Ülkeler bu faktörlere göre kümeleme analizine dahil edilmiştir:

Tablo 3: LPI Bileşenleri Bazında Ülkelerin Sıralaması (2012-2018 Dönemi)

\begin{tabular}{|c|c|c|c|c|c|c|c|}
\hline $\begin{array}{l}\text { Sir } \\
\text { a } \\
\text { No } \\
\end{array}$ & $\begin{array}{c}\text { 2012-2018 } \\
\text { LPI } \\
\text { Siralaması }\end{array}$ & $\begin{array}{c}\mathrm{X1} \\
\text { (Gümrük) }\end{array}$ & $\begin{array}{c}\mathrm{X} 2 \\
\text { (Altyapı) }\end{array}$ & $\begin{array}{c}\text { X3 } \\
\text { (Uluslararası } \\
\text { Sevkiyatlar) }\end{array}$ & $\begin{array}{c}\text { X4 } \\
\text { (Lojistik } \\
\text { Hizmet } \\
\text { Kalitesi) } \\
\end{array}$ & $\begin{array}{c}\text { X5 } \\
\text { (İzleme ve } \\
\text { Takip) }\end{array}$ & X6 (Dakiklik) \\
\hline 1 & Almanya & Almanya & Almanya & Hong Kong & Almanya & Almanya & Lüksemburg \\
\hline 2 & Hollanda & Singapur & Hollanda & Belçika & Hollanda & Amerika & Almanya \\
\hline 3 & Singapur & Hollanda & İsveç & Singapur & Belçika & Belçika & Belçika \\
\hline 4 & Belçika & Finlandiya & Singapur & Almanya & Singapur & Hollanda & Singapur \\
\hline 5 & İsveç & Danimarka & Japonya & Hollanda & İsveç & Avusturya & İsveç \\
\hline 6 & Birl. Krallık & Hong Kong & Amerika & Lüksemburg & Birl. Krallık & Birl. Krallık & Birl. Krallık \\
\hline 7 & Hong Kong & Birl. Krallık & Birl. Krallık & İsveç & Japonya & Singapur & Hollanda \\
\hline 8 & Japonya & İsveç & Belçika & Avusturya & Avusturya & Japonya & Danimarka \\
\hline 9 & Amerika & Japonya & İsviçre & Birl. Krallık & Danimarka & İsveç & Japonya \\
\hline 10 & Avusturya & İsviçre & Hong Kong & İspanya & Amerika & Hong Kong & Hong Kong \\
\hline 11 & Lüksemburg & Belçika & Fransa & Fransa & Hong Kong & Fransa & Amerika \\
\hline 12 & Danimarka & Amerika & Avusturya & Danimarka & Finlandiya & Finlandiya & Fransa \\
\hline 13 & Finlandiya & Avustralya & Kanada & BAE & Kanada & İsviçre & İsviçre \\
\hline 14 & İsviçre & Avusturya & Norveç & Finlandiya & İsviçre & Kanada & BAE \\
\hline 15 & Fransa & Lüksemburg & Finlandiya & Japonya & Lüksemburg & İrlanda & Kanada \\
\hline 16 & Kanada & Norveç & BAE & Tayvan & Fransa & Danimarka & Avusturya \\
\hline 17 & BAE & Kanada & Avustralya & İsviçre & Norveç & Lüksemburg & Finlandiya \\
\hline 18 & Avustralya & Fransa & Danimarka & İtalya & Avustralya & Avustralya & İtalya \\
\hline 19 & Norveç & BAE & Lüksembug & Çin & İspanya & İtalya & Norveç \\
\hline 20 & İspanya & YeniZelanda & İtalya & Amerika & BAE & BAE & İspanya \\
\hline 21 & İtalya & İspanya & İspanya & İrlanda & İrlanda & Norveç & Tayvan \\
\hline 22 & Tayvan & İrlanda & Kore Cumh. & Güney Afrika & Tayvan & Kore Cumh. & Avustralya \\
\hline 23 & İrlanda & Kore Cumh. & Çin & Polonya & İtalya & İspanya & İsrail \\
\hline 24 & Kore Cumh. & Tayvan & Tayvan & Kore Cumh. & Kore Cumh. & Tayvan & Kore Cumh. \\
\hline 25 & Yeni Zelanda & İtalya & \begin{tabular}{|l|} 
Yeni \\
Zelanda \\
\end{tabular} & Çekya & Çekya & Portekiz & Polonya \\
\hline 26 & Çin & GüneyAfrika & İrlanda & Norveç & Çin & GüneyAfrika & Portekiz \\
\hline 27 & Güney Afrika & İsrail & $\begin{array}{l}\text { Güney } \\
\text { Afrika }\end{array}$ & Kanada & GüneyAfrika & Macaristan & GüneyAfrika \\
\hline 28 & Portekiz & Polonya & Türkiye & Portekiz & Portekiz & YeniZel. & YeniZel. \\
\hline 29 & Çekya & Çin & Katar & Malezya & YeniZelanda & Çin & İrlanda \\
\hline 30 & Katar & Çekya & Malezya & Avustralya & İsrail & Çekya & Katar \\
\hline 31 & Polonya & Portekiz & İsrail & Katar & Katar & Katar & Çin \\
\hline 32 & Malezya & Katar & Portekiz & Tayland & Polonya & Türkiye & Çekya \\
\hline 33 & İsrail & Sili & Macaristan & Yeni Zelanda & Malezya & İsrail & Macaristan \\
\hline 34 & Türkiye & Malezya & Çekya & Macaristan & Türkiye & Polonya & Litvanya \\
\hline 35 & Macaristan & Estonya & Slovenya & Türkiye & Macaristan & Malezya & Tayland \\
\hline 36 & Tayland & Slovenya & Suudi Arab. & Panama & Slovenya & Tayland & Türkiye \\
\hline
\end{tabular}




\begin{tabular}{|c|c|c|c|c|c|c|c|}
\hline 37 & Slovenya & Tayland & Tayland & Umman & Tayland & Slovenya & Malezya \\
\hline 38 & Şili & Türkiye & Polonya & Hindistan & Hindistan & Şili & Romanya \\
\hline 39 & Estonya & Macaristan & Yunanistan & Şili & Slovakya & Bahreyn & Estonya \\
\hline 40 & Litvanya & Hirvatistan & Slovakya & Bulgaristan & Estonya & Hindistan & Slovenya \\
\hline 41 & Hindistan & Litvanya & Umman & Slovenya & Brezilya & Brezilya & Şili \\
\hline 42 & Panama & Letonya & Estonya & Slovakya & Litvanya & Suudi Arab. & Slovakya \\
\hline 43 & Slovakya & Slovakya & Panama & Vietnam & Meksika & Yunanistan & Panama \\
\hline 44 & Suudi Arab. & Bahreyn & Şili & Filipinler & Şili & Arjantin & Yunanistan \\
\hline 45 & Hirvatistan & Panama & Hirvatistan & Romanya & Hirvatistan & Endonezya & Hindistan \\
\hline 46 & Yunanistan & Hindistan & Litvanya & Estonya & Bahreyn & Litvanya & Vietnam \\
\hline 47 & Vietnam & Yunanistan & Brezilya & Meksika & Panama & Panama & Endonezya \\
\hline 48 & Bahreyn & Umman & Hindistan & Litvanya & Endonezya & Meksika & Bulgaristan \\
\hline 49 & Romanya & Vietnam & Bahreyn & Suudi Arab. & Vietnam & Romanya & Suudi Arab. \\
\hline 50 & Meksika & Romanya & Kuveyt & Bahreyn & Bulgaristan & Letonya & Meksika \\
\hline 51 & Letonya & Bulgaristan & Misir & Letonya & Suudi Arab. & Estonya & Hurvatistan \\
\hline 52 & Umman & Suudi Arab. & Meksika & Arjantin & Misir & Vietnam & Brezilya \\
\hline 53 & Bulgaristan & Kuveyt & Letonya & Endonezya & Yunanistan & Hirvatistan & Umman \\
\hline 54 & Endonezya & Meksika & Vietnam & Hirvatistan & Romanya & Ukrayna & Ukrayna \\
\hline 55 & Brezilya & Misir & Arjantin & Yunanistan & Umman & Filipinler & Letonya \\
\hline 56 & Misir & Filipinler & Bulgaristan & Misir & Letonya & Misir & Arjantin \\
\hline 57 & Arjantin & Endonezya & Romanya & İsrail & Filipinler & Slovakya & Kuveyt \\
\hline 58 & Kuveyt & Pakistan & Endonezya & Brezilya & Arjantin & Kuveyt & Peru \\
\hline 59 & Filipinler & Peru & Fas & Kenya & Sirbistan & Kenya & Kenya \\
\hline 60 & Ukrayna & Sri Lanka & Filipinler & Kuveyt & Kuveyt & Bulgaristan & Sirbistan \\
\hline 61 & Kenya & Ekvador & Ürdün & Peru & Kolombiya & Surbistan & Misir \\
\hline 62 & Surbistan & Brezilya & İran & Fas & Kenya & Umman & Tunus \\
\hline 63 & Peru & Kazakistan & Sirbistan & Pakistan & Ukrayna & Lübnan & Bahreyn \\
\hline 64 & Ekvador & Kolombiya & Peru & Surbistan & Peru & Kosta Rika & Ekvador \\
\hline 65 & Ürdün & Arjantin & Kenya & Ürdün & Pakistan & Peru & Ürdün \\
\hline 66 & Kolombiya & Guatamala & Ekvador & Ekvador & Rusya & Kazakistan & Fas \\
\hline 67 & Pakistan & Kamboçya & Kazakistan & Kamboçya & İran & Tunus & Kolombiya \\
\hline 68 & Fas & Ürdün & Azerbaycan & Kolombiya & Sri Lanka & Dom. Cumh. & Filipinler \\
\hline 69 & Kazakistan & Dom. Cumh. & Kolombiya & Dom. Cumh. & Dom. Cumh. & Ekvador & Rusya \\
\hline 70 & Kosta Rika & Ukrayna & Pakistan & Kosta Rika & Ekvador & Ürdün & Kazakistan \\
\hline 71 & Dom. Cumh. & Kenya & Rusya & Ukrayna & Kosta Rika & Sri Lanka & Guatamala \\
\hline 72 & Tunus & Sirbistan & Lübnan & Lübnan & Fas & Kamboçya & Nijerya \\
\hline 73 & Lübnan & Kosta Rika & Ukrayna & Kazakistan & Kazakistan & Nijerya & Kosta Rika \\
\hline 74 & Sri Lanka & Lübnan & Belarus & Gana & Ürdün & Rusya & Dom Cumh. \\
\hline 75 & Kamboçya & Fas & \begin{tabular}{|l|} 
Domi. \\
Cumh. \\
\end{tabular} & Sri Lanka & Bangladeş & Kolombiya & Bangladeş \\
\hline 76 & Rusya & İran & Kosta Rika & Tunus & Tunus & Pakistan & Kamboçya \\
\hline 77 & İran & Tunus & Nijerya & İran & Nijerya & Fas & Belarus \\
\hline 78 & Guatamala & Cezayir & Tunus & Guatamala & Lübnan & Cezayir & Pakistan \\
\hline 79 & Nijerya & Gana & Gana & Bangladeş & Kamboçya & Bangladeş & Lübnan \\
\hline 80 & Bangladeş & Bangladeş & Sri Lanka & Cezayir & Gana & Guatamala & Özbekistan \\
\hline 81 & Gana & Belarus & Cezayir & Venezuela & Belarus & Gana & İran \\
\hline 82 & Cezayir & Azerbaycan & Guatamala & Rusya & Guatamala & İran & Sri Lanka \\
\hline 83 & Belarus & Myanmar & Bangladeş & Belarus & Cezayir & Venezuela & Cezayir \\
\hline 84 & Venezuela & Nijerya & Kamboçya & Nijerya & Özbekistan & Özbekistan & Gana \\
\hline
\end{tabular}


Türkiye'nin Uluslararası Lojistik Performans Endeksindeki Konumunun Kümeleme Analizi...1671

\begin{tabular}{|l|l|l|l|l|l|l|l|}
\hline \hline 85 & Azerbaycan & Rusya & Özbekistan & Azerbaycan & Venezuela & Azerbaycan & Venezuela \\
\hline 86 & Özbekistan & Özbekistan & Venezuela & Angola & Myanmar & Belarus & Azerbaycan \\
\hline 87 & Myanmar & Libya & Angola & Özbekistan & Libya & Myanmar & Myanmar \\
\hline 88 & Libya & Venezuela & Myanmar & Irak & Angola & Angola & Irak \\
\hline 89 & Angola & Angola & Libya & Libya & Azerbaycan & Libya & Libya \\
\hline 90 & Irak & Irak & Irak & Myanmar & Irak & Irak & Angola \\
\hline \multicolumn{2}{c}{ Tablo Kaynak: }
\end{tabular}

https://lpi.worldbank.org/sites/default/files/International_LPI_from_2007_to_2018.xlsx adresinden alınmıştır.)

Tablo 3'te ülkelerin, uluslararası LPI 2012, 2014, 2016 ve 2018 yıllarına ait skorlarının aritmetik ortalamaları alınmış şekilde sıralaması yer almaktadır. Türkiye genel sıralamada kendine 34. Sırada yer bulmuştur. Alt bileşenlere bakıldığında ise Türkiye'nin, "gümrükler" bileşeninde 38. sırada, "altyapı"da 28. sirada, "yükleme"de 35. sırada, "lojistik hizmet kalitesi"nde 34. sirada, “izleme"de 32. sırada ve "dakiklik"te ise 36. sırada yer aldığı görülmektedir.

\section{Bulguların Değerlendirilmesi}

Hiyerarşik kümeleme analizi neticesinde elde edilen dendogram Şekil 4'te yer almaktadır. Küme sayısının belirlenmesinde dendogram üzerinde 12,5 birim mesafe baz alınmıştır. Bu noktada, 90 ülkenin 14 küme oluşturduğu görülmektedir. Dendogramdan elde edilen ülkelerin dâhil oldukları kümeler Tablo 4’te yer almaktadır. 


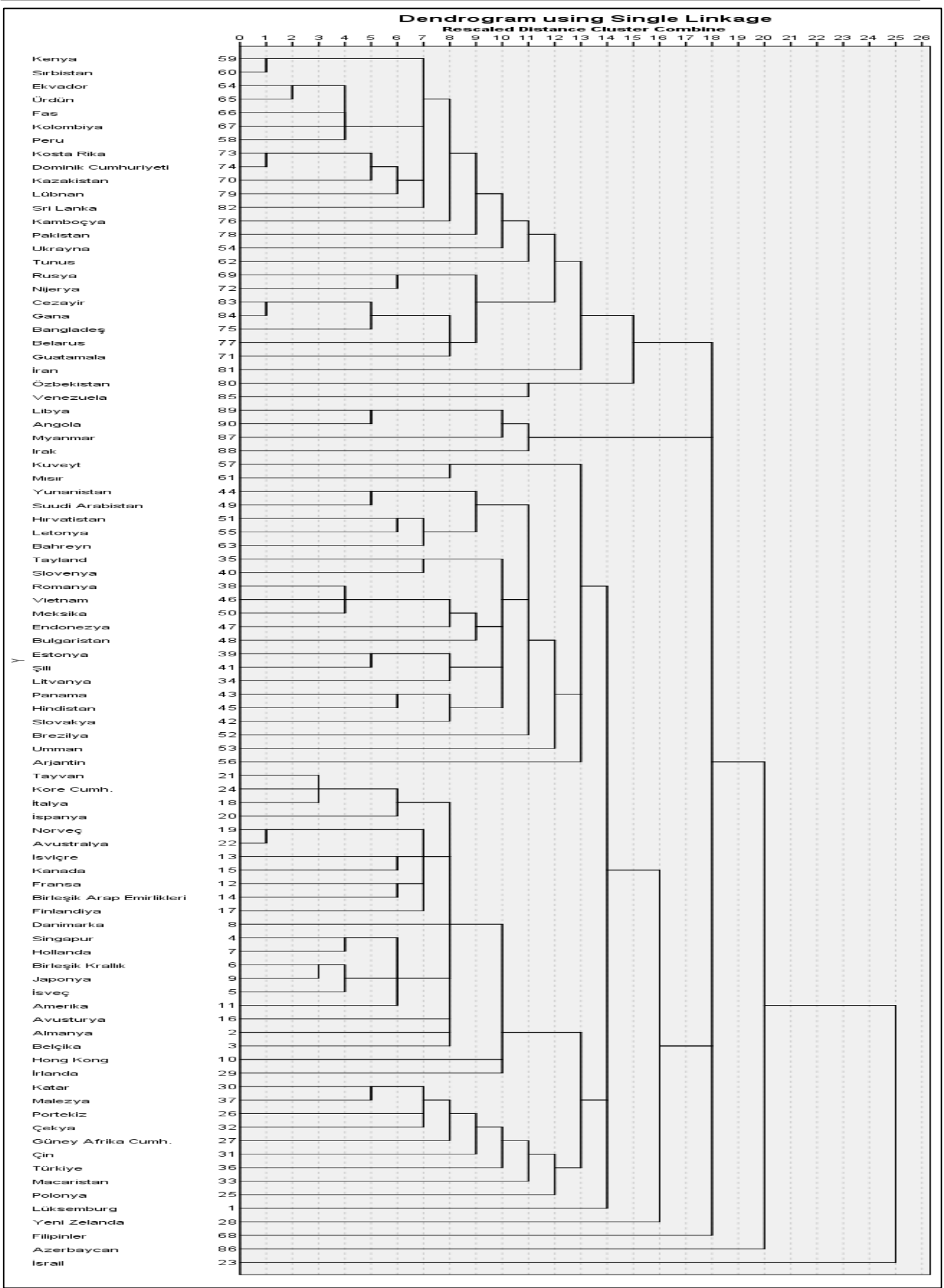

Şekil 4. Lpi Dendogram Bulguları 
Türkiye’nin Uluslararası Lojistik Performans Endeksindeki Konumunun Kümeleme Analizi...1673

Tablo 4: Lpi Ülke Kümeleri

\begin{tabular}{|c|l|c|}
\hline $\begin{array}{c}\text { Küme } \\
\text { No }\end{array}$ & Ülkeler & $\begin{array}{c}\text { Kümedeki } \\
\text { Ülke Sayısi }\end{array}$ \\
\hline $\mathbf{1}$ & $\begin{array}{l}\text { Kenya, Sırbistan, Ekvador, Ürdün, Fas, Kolombiya, Peru, Kosta Rika, Dominik Cum., } \\
\text { Kazakistan, Lübnan, Sri Lanka, Kamboçya, Pakistan, Ukrayna, Tunus, Rusya, Nijerya, } \\
\text { Cezayir, Gana, Banglades,, Belarus, Guatemala }\end{array}$ & 23 \\
\hline $\mathbf{2}$ & İran & 1 \\
\hline $\mathbf{3}$ & Özbekistan, Venezuela & 2 \\
\hline $\mathbf{4}$ & Libya, Angola, Myanmar, Irak & 4 \\
\hline $\mathbf{5}$ & Kuveyt, Mısır & 2 \\
\hline $\mathbf{6}$ & $\begin{array}{l}\text { Yunanistan, Suudi Arabistan, Hırvatistan, Letonya, Bahreyn, Tayland, Slovenya, } \\
\text { Romanya, Vietnam, Meksika, Endonezya, Bulgaristan, Estonya, Şili, Litvanya, }\end{array}$ & 20 \\
\hline $\mathbf{7}$ & Panama, Hindistan, Slovakya, Brezilya, Umman & 1 \\
\hline $\mathbf{8}$ & $\begin{array}{l}\text { Tayvan, Kore Cum., İtalya, İspanya, Norveç, Avustralya, İsviçre, Kanada, Fransa, } \\
\text { Birleşik Arap Emirlikleri (BAE), Finlandiya, Danimarka, Singapur, Hollanda, Birleşik } \\
\text { Krallı, Japonya, İsveç, Amerika, Avusturya, Almanya, Belçika, Hong Kong, Irlanda }\end{array}$ & 23 \\
\hline $\mathbf{9}$ & $\begin{array}{l}\text { Türkiye, Katar, Malezya, Portekiz, Çekya, Güney Afrika Cum., Çin, Macaristan, } \\
\text { Polonya }\end{array}$ & 9 \\
\hline $\mathbf{1 0}$ & Lüksemburg & 1 \\
\hline $\mathbf{1 1}$ & Yeni Zelanda & 1 \\
\hline $\mathbf{1 2}$ & Filipinler & 1 \\
\hline $\mathbf{1 3}$ & Azerbaycan & 1 \\
\hline $\mathbf{1 4}$ & İsrail & 1 \\
\hline & Kaynariana & \\
\hline
\end{tabular}

(Kaynak: Tablo yazar tarafindan oluşturulmuştur.)

Tablo 5'te analize dahil edilen 90 ülkenin 2012, 2014, 2016 ve 2018 y1llarına ait genel ortalama LPI skorunun 3,20 olduğu görülmektedir. Dünya Bankasından (World Bank1) elde edilen verilere göre, Tablo 4'te görülen ve birinci kümede yer alan ülkelerin genel LPI siralamasında 2,71 skor ile ortalamanın altında performans gösterdikleri görülmektedir. İkinci kümede yer alan İran'ın, "izleme-takip" ve "dakiklik" değişkenlerinde birinci küme ülkelerine göre daha düşük performans nedeniyle ayrı küme oluşturduğu düşünülmektedir. Üçüncü ve dördüncü küme ülkeler, tüm ülkeler arasında 2,47 ve 2,28 ile en düşük LPI ortalamasına sahip ülkeler olarak gruplanmıştır. Beşinci, yedinci ve on ikinci kümede yer alan Misır, Kuveyt, Arjantin ve Filipinler'in 2,97 ile birbirine yakın performans sergilediği görülmektedir. Altıncı kümede yer alan 20 ülkenin 3,14 ile genel ortalamaya yakın olduğu görülmektedir. Sekizinci kümedeki 23 ülkenin, 3,88 ortalama ile en iyi performans sergileyen grup olduğu not edilmelidir. Onuncu kümede yer alan Lüksemburg'un, sekizinci kümedeki ülkeler ile benzer ortalamaya sahip olmasına rağmen, "lojistik hizmet kalitesi" değişkeninde $\% 3,89$, "dakiklik" değişkeninde ise $\% 5,73$ daha iyi performans sergilemesinden dolay1 ayrı küme oluşturduğu düşünülmektedir. On birinci kümede yer alan Yeni Zelanda, dokuzuncu küme ülkeleri ile yakın genel ortalamaya sahip olmasına rağmen, "gümrük" değişkeninde \%36 ve "altyapı" değişkeninde \%28 daha iyi performans sergilediği, buna karşın "uluslararası sevkiyat" değişkeninde ise \%15 daha düşük performans sergilemesi nedeniyle farklı küme oluşturmuştur. On üçüncü kümedeki Azerbaycan'ın genel ortalama skorunun üçüncü kümeye yakın olmasına rağmen, "altyapı" değişkeninde \%26 daha iyi, "lojistik hizmet kalitesi" değişkeninde ise \%28 daha düşük performans göstermesinden dolayı ayrı küme oluşturduğu düşünülmektedir. On dördüncü kümede yer alan İsrail genel ortalama skorunun dokuzuncu kümeye yakın olmasına rağmen, "uluslararası sevkiyat" değişkeninde \%48 daha düşük performans göstermesinden dolayı ayrı kümede yer almıştır. 
Tablo 5'te görüldüğü üzere Türkiye, son sekiz yılın ortalamasında 90 ülke içerisinde tüm değişkenlerde 3,39 ile ortalamanın üzerinde performans sergileyerek 34. sırada yer almıştır. Dokuzuncu küme, "Türkiye, Katar, Malezya, Portekiz, Çekya, Güney Afrika Cumhuriyeti, Çin, Macaristan ve Polonya"dan oluşmaktadır. Dokuzuncu küme ülkeleri, 3,48 ortalama LPI skoru ile en iyi performansı sergileyen ikinci kümedir. Dünya Bankasının 2017 verisine göre Türkiye, Çin, Malezya ve Güney Afrika üst orta gelirli ülkeler arasında yer alırken; Katar, Portekiz, Çekya, Macaristan ve Polonya üst gelirli ülkeler arasında yer almaktadır (WorldBank2, 2018). Analiz sonuçları, gelişmekte olan ülkelerin lojistik performanslarının yüksek gelirli ülkelere nazaran daha fazla arttığını ifade eden Arvis vd.'nin (2018) bulgularılla örtüşmektedir.

Tablo 5: Lpi Alt Değişken Ortalamaları

\begin{tabular}{|c|c|c|c|c|c|c|c|}
\hline Ülke/Küme & LPI Ort. & X1 & X2 & X3 & X4 & X5 & X6 \\
\hline 90 Ülke & 3,20 & 2,97 & 3,12 & 3,13 & 3,15 & 3,23 & 3,58 \\
\hline 9. Küme & 3,48 & 3,21 & 3,38 & 3,44 & 3,45 & 3,55 & 3,84 \\
\hline Türkiye & 3,39 & 3,07 & 3,46 & 3,26 & 3,38 & 3,48 & 3,73 \\
\hline
\end{tabular}

(Kaynak: Tablo yazar tarafindan oluşturulmuştur.)

Türkiye'nin kümedeki konumu, Şekil 4'te yer alan dendogram ile Tablo 3'te yer alan ülkelerin LPI sıralamasına göre aşağıda altı değişken bazında maddeler halinde değerlendirilmiştir:

\section{i. X1 (Gümrük)}

Türkiye gümrük değişkeni genel sıralamasında 38. sıra ile kümede en düşük performans sergileyen Macaristan ile yakınlık içerisinde iken, yüksek performans gösteren Çin, Polonya ve Güney Afrika Cumhuriyeti ile uzak benzerlik içerisinde yer almaktadır.

\section{ii. X2 (Altyapı)}

Türkiye, altyapı değişkeninde tüm ülkeler arasında 28. sırada yer almaktadır. Küme ülkeleri arasında en çok Güney Afrika, Katar ve Malezya ile yakın performans sergilemekte iken, Çin ve Polonya ile uzak benzerlik göstermiştir. Çin, altyapı hizmetlerinde kümede en iyi performansa sahip ülke iken, Polonya en düşük performansa sahip ülke olarak görülmüştür.

\section{iii. $\quad$ X3 (Uluslararası sevkiyatlar)}

Türkiye, uluslararası sevkiyat değişkeninde tüm ülkeler arasında 35. sırada yer alarak, kümede en düşük performansa sahip ülke olarak görülmektedir. Küme ülkeleri içerisinde Macaristan ile en yakın benzerliğe sahipken, en iyi performansa sahip Çin ile uzak benzerlik göstermektedir. En yüksek performans bakımından Çin'i, Güney Afrika Cumhuriyeti ve Polonya takip etmektedir.

\section{iv. X4 (Lojistik hizmet kalitesi)}

Lojistik hizmet kalitesi değişkeninde Türkiye, tüm ülkeler arasında 34. olarak, kümede en düşük performans gösteren Macaristan ve Malezya ile yakın benzerlik içerisindedir. Türkiye; Çin, Güney Afrika ve Portekiz'in altında performans sergilemesine rağmen, bu ülkelere yakın benzerlik göstermektedir.

\section{v. X5 (İzleme ve takip)}

Türkiye, izleme ve takip değişkeninde tüm ülkeler içerisinde ortalamada 32. sırada yer almıştır. Türkiye, kümede orta seviyelerde performans göstererek Katar ile yakın benzerlik kurmuştur. $\mathrm{Bu}$ değişkende en iyi performansı sırayla Portekiz, Güney Afrika ve Macaristan gösterirken, en düşük performansı ise Polonya ve Malezya göstermiştir. 


\section{vi. $\quad$ X6 (Dakiklik)}

Türkiye, dakiklik değişkeninde tüm ülkeler içerisinde ortalamada 36. sırada yer almıştır. Kümede en iyi performansı sergileyen ülkeler sırasıyla Polonya, Portekiz ve Güney Afrika olurken, en düşük performansı ise Türkiye ve Malezya göstermiştir. Bu değişkende Çin'in, diğer değişkenlere nazaran daha düşük performans sergilediği ve orta sıralarda yer bulduğu görülmüştür.

\section{Sonuç ve Öneriler}

Küresel ekonomilerin iç içe olduğu dünyada, ülkelerin ulusal ya da uluslararası ticarette rekabet edebilmelerinde en önemli etkenlerden birisi lojistik performanslarının etkinliği ve verimliğidir. Dünya Bankası tarafindan oluşturulan LPI, ülkelerin lojistik performanslarında karşılaştıkları tehdit ve firsatlar ile performanslarını iyileştirmek için oluşturulan bir kıyaslama aracıdır. Ülkelerin ticaret yeteneğinin geliştirilmesi ve uluslararası rekabet gücünün artırılabilmesi için lojistik sektöründe düzenlemelerin yapılması oldukça önemlidir. Bu çalışma uluslararası LPI'ya göre 2012-2018 yılları arasında Türkiye'nin hangi ülkeler ile benzerlik gösterdiğini araştırmayı amaçlamıştır. LPI alt bileşenleri bazında Türkiye'nin dünyadaki konumu araştırılarak, Türkiye'nin lojistik performansı ile bu konudaki zayıf ve güçlü yönleri belirlenmeye çalışılmıştır.

Çalışmada 2017 yılı dış ticaret hacmi en fazla olan 90 ülke ele alınmıştır. Bu ülkelerin 2012, 2014, 2016 ve 2018 yıllarına ait LPI verilerinin ortalamaları altı değişken bazında kümeleme analizi yöntemiyle araştırılmıştır. Ülkeler on dört kümede toplanmıştır. Türkiye; Katar, Malezya, Portekiz, Çekya, Güney Afrika Cumhuriyeti, Çin, Macaristan ve Polonya ile aynı kümede yer almıştır.

Türkiye dünya ülkeleri arasında 34. sırada yer bularak LPI ortalamasının üzerinde performans göstermiştir. Türkiye'nin, içinde bulunduğu kümede gümrük, uluslararası sevkiyat, lojistik hizmet kalitesi ve dakiklik değişkenlerinde küme performansının altında performans sergilediği, altyapı değişkeninde grup ülkelerine göre daha iyi performans gösterdiği, izleme değişkeninde ise grup ortalamasında performans sergilediği bulgulanmıştır. OECD (2015) verilerine göre Türkiye'nin yaptığı büyük çaptaki alt yapı yatırımlarının LPI'da altyapı performansını iyileştirdiği, böylece ülkeler arasında sıralamasını yükselttiği düşünülmektedir.

Buna mukabil, Türkiye'nin lojistik performans endeksinde üst sıralara çıkması adına sunulabilecek öneriler aşağıdaki gibidir:

- Türkiye'de en çok kullanılan taşımacılık modu olan denizyolu taşımacılığında yatırımlarının artırılması sonucunda etkinlik ve verimlilikte artış kaydedilebilir.

- Lojistik bilgi sistemlerinin işletmelerce kullanımının yaygınlaştırılması ve lojistik ağındaki kullanıcılar arasında bütünleşik hale getirilebilmesi faydalı olabilir.

- Türkiye, elektronik gümrük uygulamalarına ağırlık vermek suretiyle ithalat ve ihracat süreleri ile fiziki kontrol, bekleme ve gecikme sürelerini azaltarak gümrük performansını artır1labilir.

- Rekabetçi fiyatların sunulabilmesi için yük doluluk oranlarının artırılması, hedef pazara en uygun taşıma modunun seçilmesi, deniz limanlarının sayı ve etkinliğinin artırılması ve çok modlu taşıma sistemlerinin entegre olması sağlanabilir.

- Limanların iç bölgelerle bağlantıları geliştirilerek, ulaşım süreleri kısaltılabilir. Limanlar ile üretim sahaları arasındaki bağlantılar artırılarak lojistik süresi kısaltılabilir.

- Bilgi ve iletişim teknolojilerine daha fazla yatırım yapılarak uzun vadede lojistik faaliyetlerin izlenme ve kalite kontrol performansında gelişmeler kaydedilebilir. 
- Sınır geçişlerinde öngörülemeyen durumlar ve gecikmelerin en aza indirilmesi için ticaret yapılan ülkeler ile işbirliğine gidilmesi ve lojistik süreçlerin uluslararası çapta elektronik ortama taşınarak entegrasyonu sağlanabilir.

Bu çalışmada veri seti ülkelerin dış ticaret hacmi baz alınarak oluşturulmuştur. Ancak, LPI performansı ülkelerin gelir seviyelerine göre de farklılık göstermektedir. Araştırmacılar ülkelerin gelir seviyelerini ya da uluslararası ekonomik birlikleri baz alarak LPI performanslarını inceleyebilir. Aynı veri setinde yer alan ülkelerin performansları, farklı dönemler baz alınarak araştırılabilir.

\section{Kaynakça}

Akçetin, E., Çelik, Ö. G. U. ve Takçı, H. (2015). Lojistik ve Denizcilik Sektörü Açısından Veri Madenciliği Uygulamalarının Önemi. Journal of ETA Maritime Science, 1(2), 73-80.

Akçetin, E. (2010). Avrupa Birliğine Üyelik Sürecinde Küresel Lojistik Üs Olma Yolunda Türkiye. Adıyaman Üniversitesi Sosyal Bilimler Enstitüsü Dergisi, 2010(5), 1-14. https://doi.org/10.14520/adyusbd.90

Akiş, E. (2016). Lojistik Sektörü ve Rekabet Gücüne Etkisi. 2.Üretim Ekonomisi Kongresi 11-12 Nisan, www.iku.edu.tr. İstanbul.

Arvis, J. F., Ojala, L., Wiederer, C., Shepherd, B., Raj, A., Dairabayeva, K. ve Kiiski, T. (2018). Connecting to Compete, https://openknowledge.worldbank.org/handle/10986/29971.

Arvis, J. F., Saslavsky, D., Ojala, L., Shepherd, B., Busch, C., Raj, A. ve Naula T. (2016). Connecting To Compete 2016: Trade Logistics in The Global Economy, The Logistics Performance Index and Its Indicators.

Arvis, J. F., Mustra, M. A., Ojala, L., Shepherd, B. ve Saslavsky, D. (2014). Connecting to Compete. Trade Logistics in The Global Economy. The Logistics Performance Index and Its Indicators Available at: http://siteresources. worldbank. org/INTTLF/Resources/lpireport. pdf, Accessed on August.

Arvis, J. F., Mustra, M. A., Ojala, L., Shepherd, B. ve Saslavsky, D. (2012). Connecting to Compete 2012: Trade Logistics in The Global Economy.

Arvis, J. F., Mustra, M. A., Ojala, L., Shepherd, B. ve Saslavsky, D. (2010). Connecting to Compete 2010: The Logistics Performance Index and Its Indicators. World Bank, Washington, DC. C) World Bank. https://openknowledge.worldbank.org/handle/10986/24599 License: CC BY 3.0 IGO

Arvis, J.-F., Mustra, M. A., Panzer, J., Ojala, L., ve Naula, T. (2007). Connecting to Compete 2007: Trade Logistics in the Global Economy-The Logistics Performance Index and Its Indicators, World Bank, Washington, DC. (C) World Bank. https://openknowledge.worldbank.org/handle/10986/24600 License: CC BY 3.0 IGO

Azmat, G. (2017). The Logistics Performance Effect in International Trade. Asian Journal Of Shipping And Logistics, Vol 33, Iss 4. http://dx.doi.org/10.1016/j.ajsl.2017.12.012

Baki, B. ve Şimşek, B. (2004). Lojistik Faaliyetlere Göre Performans Ölçütlerinin Belirlenmesi. Yöneylem Araştırması/Endüstri Mühendisliği XXIV Ulusal Kongresi, 15-18.

Başar, S. İ. ve Bozma, G. (2017). Ülkelerin Lojistik Performanslarının Belirleyicileri. Kafkas Üniversitesi Sosyal Bilimler Enstitüsü Dergisi. 2017(20), 447-458. http://dx.doi.org/10.9775/kausbed.2017.028 
Türkiye’nin Uluslararası Lojistik Performans Endeksindeki Konumunun Kümeleme Analizi...1677

Bayraktutan, Y. ve Özbilgin, M. (2015). Lojistik Maliyetler ve Lojistik Performans Ölçütleri. Maliye Araştırmaları Dergisi, 1(2), 95-112.

Bayraktutan, Y., Tüylüoğlu, Ş. ve Özbilgin, M. (2012). Lojistik Sektöründe Yoğunlaşma Analizi ve Lojistik Gelişmişlik Endeksi: Kocaeli Örneği. Journal of Alanya Faculty of Business, 4(3), 61-71.

Burmaoğlu, S. (2012). Ulusal İnovasyon Göstergeleri ile Ulusal Lojistik Performansı Arasındaki İlişki: AB Ülkeleri Üzerine Bir Araştırma. Ege Akademik Bakış, 12(2), 193-208.

Civelek, M. E., Uca, N. ve Cemberci, M. (2015). The Mediator Effect of Logistics Performance İndex on The Relation Between Global Competitiveness Index and Gross Domestic Product. European Scientific Journal, ESJ, 11(13), 368-375.

Çakmak Aynagöz, Ö. (2016). Wto-Ticareti Kolaylaştırma Anlaşması ve Türkiye İçin Değerlendirmeler. Afyon Kocatepe Üniversitesi İktisadi ve İdari Bilimler Fakültesi Dergisi, 18(1), 1-13. http://dx.doi.org/10.5578/jeas.26363

Çelebi, Ü. ve Civelek, M. E. (2019). The Mediator Role of Global Connectedness in The Relationship Between Logistics Performance and Human Development. Business \& Management Studies: An International Journal, 6(4), 969-980.

D'Aleo, V. (2015). The Mediator Role of Logistic Performance Index: A Comparative Study. Journal of International Trade, Logistics and Law, 1(1), 1-7.

Demir, M. H. (2013), Çağdaş Lojistik Uygulamaları, T.C. Anadolu Üniversitesi Yayını No: 2752

Ener, T. (2010). Küresel Lojistik Performans İndeksi: Mersin'de Faaliyet Gösteren Lojistik Firmalarının Sektörel Performanslarının İncelenmesi. Yüksek Lisans Tezi. Mersin Üniversitesi Sosyal Bilimler Enstitüsü.

Erkan, B. (2014). The Importance and Determinants of Logistics Performance of Selected Countries. Journal of Emerging Issues in Economics, Finance and Banking, 3(6), 12371254.

Fugate, B. S., Mentzer, J. T. ve Stank, T. P. (2010). Logistics Performance: Efficiency, Effectiveness, and Differentiation. Journal of Business Logistics, 31(1), 43-62.

Gergin, R. E. ve Baki, B. (2015). Türkiye'deki Bölgelerin Lojistik Performanslarının Bütünleştirilmiş AHS ve TOPSIS Yöntemiyle Değerlendirilmesi. Business and Economics Research Journal, 6(4), 115-135.

Güner, S. ve Coşkun, E. (2012). Comparison of Impacts of Economic and Social Factors on Countries' Logistics Performances: A Study With 26 OECD Countries. Research in Logistics \& Production, 2, 330-343.

Gülenç, İ. F. ve Karagöz, B. (2008). E-lojistik ve Türkiye'de E-Lojistik Uygulamaları. Kocaeli Üniversitesi Sosyal Bilimler Enstitüsü Dergisi, (15), 73-91.

Havenga, J. H. (2011). Trade Facilitation Through Logistics Performance: The Enabling Role of National Government. Journal of Transport and Supply Chain Management, Vol 5, Iss 1, Pp 123-148 (2011), (1), 123-148. https://doi.org/10.4102/jtscm.v5i1.25

Hung Lau, K. (2011). Benchmarking Green Logistics Performance With A Composite Index. Benchmarking: An International Journal, 18(6), 873-896.

Khan, S. A. R., Qianli, D., SongBo, W., Zaman, K. ve Zhang, Y. (2017). Environmental Logistics Performance Indicators Affecting Per Capita Income and Sectoral Growth: Evidence From 
A Panel of Selected Global Ranked Logistics Countries. Environmental Science and Pollution Research, 24(2), 1518-1531.

Kunadhamraks, P. ve Hanaoka, S. (2008). Evaluating The Logistics Performance of Intermodal Transportation in Thailand. Asia Pacific Journal of Marketing and Logistics, 20(3), 323342.

LPI, WorldBank;

https://lpi.worldbank.org/sites/default/files/International_LPI_from_2007_to_2018.xlsx, Erişim Tarihi 15/11/2018.

Martí, L., Martín, J. C. ve Puertas, R. (2017). A Dea-Logistics Performance Index. Journal Of Applied Economics, 20(1), 169-192.

Martí, L., Puertas, R. ve García, L. (2014). The Importance of The Logistics Performance Index in International Trade. Applied Economics, 46(24), 2982-2992.

Meçik, O. (2012). Ulaştırma Ağlarının Ekonomik Entegrasyonlara Etkisi ve Türk Dünyası Boyutu. Uşak Üniversitesi Sosyal Bilimler Dergisi, 5(2), 22-33.

Mundial, B. (2011). The Logistic Performance Index and Its Indicator: Connecting To Compete. Trade Logistic in the Global Economy, Banco Mundial, Washington, DC, USA.

Mutlu, H. M. ve Ölmez, A. G. S. (2017). Lojistik Performans ve İlişki Kalitesi Üzerine Alanyazın İncelemesi. Uluslararası Ticaret ve Ekonomi Araştırmaları Dergisi, 1(2), 99-120.

Navickas, V., Sujeta, L. ve Vojtovich, S. (2011). Logistics Systems As A Factor of Country's Competitiveness. Economics and Management, 16(1), 231-237.

Nordas, H. K. (2006). Time As A Trade Barrier: İmplications For Low-İncome Countries. OECD Economic Studies (p. 137). OECD Publications and Information Centre. http://search.ebscohost.com/login.aspx?direct=true \&db=edsgao\&AN=edsgcl.164871308\&1 ang $=$ tr\&site $=$ eds-live

OECD. (2015). Drivers of Logistics Performance: A Case Study of Turkey. International Transport Forum Policy Papers, https://doi.org/10.1787/5jlwvzd3pks2-en

Ojala, L. ve Çelebi, D. (2015). The World Bank's Logistics Performance Index (LPI) and Drivers of Logistics Performance. Document Préparé Pour La Table Ronde Du Forum International Des Transports Sur Les Stratégies De Développement Logistique Et Leurs Indicateurs De Résultats (9-10 mars 2015, Queretaro, Mexique).

Onay, M. ve Kara, S. (2009). Lojistik Dış Kaynaklama Uygulamalarının Örgüt Performansı Üzerine Etkileri. Ege Academic Review, 9(2), 593-622.

Ofluoğlu, N , Kalaycı, C , Artan, S , Bal, H . (2018). Lojistik Performansındaki Gelişmelerin Uluslararası Ticaret Üzerindeki Etkileri: $\mathrm{AB}$ ve MENA Ülkeleri Örneği. Gümüşhane Üniversitesi Sosyal Bilimler Enstitüsü Elektronik Dergisi, 9 (24), 92-109.

Puertas, R., Martí, L. ve García, L. (2014). Logistics Performance and Export Competitiveness: European Experience. Empirica, 41(3), 467-480.

Ranjit, G. (2016). "Exploring The Logistics Performance Index: Cross Country Comparisons of India's Trade Logistics Performance with other Countries." IPE Journal of Management 6(2)1-13.

Saatçioğlu, C. ve Karaca, O. (2013). Ulaştırma Altyapısı ve Bölgesel Gelir Farklılıkları: Türkiye İçin Ampirik Bir Analiz. İsletme ve İktisat Çalışmaları Dergisi, 1(1), 1-11. 
Türkiye’nin Uluslararası Lojistik Performans Endeksindeki Konumunun Kümeleme Analizi...1679

Sarıman, G. (2011). Veri Madenciliğinde Kümeleme Teknikleri Üzerine Bir Çalışma: K-means ve K-medoids Kümeleme Algoritmalarının Karşılaştırılması. Süleyman Demirel Üniversitesi Fen Bilimleri Enstitüsü Dergisi, 15(3), 192-202.

Sofyalığlu, Ç. ve Kartal, B. (2013). Türkiye ve Avrasya Ekonomik Topluluğu Ülkelerinin Lojistik Performans İndekslerinin Karşılaştırılması ve Bazı Çıkarımlar. International Conference on Eurasian Economies, 524-531.

TÜİK, 2018; http://tuik.gov.tr/PreIstatistikTablo.do?istab_id=621, Erişim Tarihi, 19/11/2018.

UAB (2016). İstatistiklerle Ulaştırma ve Altyapı Bakanlığ 1 2003-2016. ISBN 978-975-493-091-7. http://www.udhb.gov.tr/images/istatistik/2003-2016.pdf, Erişim Tarihi, 19/11/2018.

Vilko, J., Karandassov, B. ve Myller, E. (2011). Logistic Infrastructure and Its Effects on Economic Development. China-USA Business Review, 10(11), 1152-1167. https://doi.org/10.17265/1537-1514/2011.11.009

WorldBank1, https://lpi.worldbank.org. Erişim Tarihi, 19/11/2018

WorldBank2，2018. https://data.worldbank.org/indicator/ny.gnp.pcap.cd?year_high_desc=true Erişim Tarihi, 20/11/2018.

WTO1, World Trade Report (2004). Exploring The Linkage Between The Domestic Policy Environment and International Trade, 1-276.

WTO2, http://stat.wto.org/StatisticalProgram/WSDBViewData.aspx?Language=E, Erişim Tarihi 25/10/2018.

Yapraklı, T. Ş. ve Ünalan, M. (2017). Küresel Lojistik Performans Endeksi ve Türkiye'nin Son 10 Y1llık Lojistik Performansının Analizi. Ataturk University Journal of Economics \& Administrative Sciences, 31(3), 589-606.

Yılmaz, Ş. K. ve Patır, S. (2011). Kümeleme Analizi ve Pazarlamada Kullanımı. Akademik Yaklaşımlar Dergisi 2(1), 91-113.

Yu, M.-M. ve Hsiao, B. (2016). Measuring The Technology Gap and Logistics Performance of Individual Countries By Using A Meta-Dea-Ar Model. Maritime Policy \& Management, 43(1), 98-120. 